\title{
Effect of TRX exercises on the improvement of some physical fitness elements and on performance level for female players on ergometer \\ *Dr/ Samaa Abdel Dayem Mohamed Ali
}

\section{Introduction:}

The scientific and technological progress which witnessed by the world today in all areas and activities of life drives the workers in the field of sports to search for everything new and modern in this area, where the era we live in the vast development in the potential used in the field of sports,

In addition, racing all countries to benefit from These possibilities, which include various sports equipment and devices, must be adapted to the player's interest in order to encourage him to do more activity and interact in training.

Koprince

(2009)

points out that training with modern equipment is one of the essentials of physical preparation, which has become a necessary requirement in the various sports activities that can be carried out whether these activities are individual or collective. An effective method has an impact on the development of special abilities in Different sports. (22: 51)

Allawi stressed that the tools and assistive devices are important and effective in the positive impact on the training and good extraction, it raises the activity and enthusiasm of the players as well as it is the latest means of thrill and diversification (11: 17)

$\begin{array}{cc}\text { Kitchhner } & (2000) \\ \text { refers to the recent }\end{array}$ proliferation of some training with tools that help develop the fitness elements of practitioners, most notably the TRX, originally designed by a member of the US Navy who needs to maintain their physical fitness on an ongoing basis

It is a type of training that uses gravity and body

Lecturer, Aquatics Sports Training Department, Faculty of physical Education, Helwan University, Egypt 
weight to build strength, ability, balance, muscular compatibility and flexibility, and hardness of center muscles, while preventing many injuries. It is the use of two non-rubber cords on the feet or hands to carry the body in part, by many of the run Sports professionals all over the world. (21: 201) (29) (23)

Weijun (2011) notes that suspension training is symbolized by the symbol TRX, which means full body resistance exercise, which is suitable for beginners and high-caliber, and can be graded by changing the position of the body relative to the point of attachment(. : 140)

TRX is a new method of fitness training that has become popular in recent years, focusing on using the full weight of the human body in training rather than using the equipment in the fitness halls (22: 51) (30) (24:84)

\section{Johannes Aartun}

(2011) notes that attachment training is one of the latest technologies in the sports field to improve athletic performance and gain a competitive edge. (32)
Victor Dulceață

(2011) emphasizes that suspension training is a revolution in the world of sports training. It is an advanced form of resistance training. It aims to develop muscle strength in all its forms without using weight or other forms of resistance. It uses only body weight as a natural resistance to performance. . (110: 25)

And that the training of attachment is a simple exercise and not easy, and this is evident in the fact that the exercises are characterized by simplicity and can be graduated in the intensity of the weak intensity of the maximum, and is aimed at improving balance, flexibility, compatibility and muscle strength.

Physical attributes are one of the factors on which performance is based on achieving the highest levels. The development of these special qualities is closely related to the process of developing the basic motor skills of the type of sports activity in which it is specialized in the absence of the physical qualities necessary 
for this particular type of sports activity. : 81)

In this regard, Khalid

Abdel-Karim (2002) refers to the importance of developing muscular capacity because of its positive impact on progress in the digital level, showing the importance of muscular capacity in muscular activities of continuity and rapid repetition,

Which is characterized by strength with speed as in the sport of rowing, therefore, the rowing player must have a high muscular capacity so that he can produce a high degree of driving force for the two men as well as a high degree of speed when performing the required skill. (3:20)

Muscle strength is associated with maximum strength and is developed by similar training methods, and the increase in strength or velocity will lead to an increase in muscle capacity and when capacity increases, greater strength can be achieved in less time. (68:5)

The training of heavy weights is considered an effective means of training, which aims to provide the individual with different physical and motor abilities. Most athletes use it during the preparation period for various sports activities. It includes organized exercises for different muscle groups using various weight weights. (76: 1 (V7:1).

The researcher noted the weakness of the level of rowing in some clubs because of their low physical level and that there is a shortage of trainers to develop the strength component of the formations that fit the nature of the artistic performance of the sport Rowing, which depends mainly on the strength of the muscles of the arms, legs and trunk to produce the necessary force to move forward is a sport requires the work of muscle symmetrical arms and then movement of the trunk and then the muscle capacity of the lower limb muscles, and through what I saw (19), (27), (28),

Which indicate that the use of the TRX training tool in improving the strength component is beneficial to the physical characteristics associated with the youth as an alternative tool for the use of weight training at that stage 
because of its multiple requirements In addition, the excessive use of weight training for young people may lead to the weakness of some other qualities such as flexibility and compatibility, which affect the level of rowing players, which prompted the researcher to try to use a method that improves the level of physical qualities, avoiding what may occur excessive weight training, Resistors to muscles The Argometer has become a separate contender and is now practicing not only for movement training, but to achieve standard numbers and achieve results it requires high physical performance.

Hence, the idea of research is to make a proposed program using TRX To develop the strength of the researcher's hope that it may improve the level of artistic performance of women in rowing sport on the Argometer

\section{Research goals:}

The aim of the research is to identify the impact of training by using the TRX device, which depends on:

1-Improve some fitness elements for rowing players.

$r$-Improve the level of performance on the Argometer machine for rowing players.

\section{Research hypotheses}

There are statistically significant differences between the pre measurement and the post-measurement of the experimental group

For the benefit of telemetry in improving some of the elements of fitness and performance level of rowing players There are statistically significant differences between the pre-measurement and the post-measurement of the control group

For the benefit of telemetry in some elements of fitness and performance level of rowing players.

There are statistically significant differences between the two dimensions of the control group (style Traditional) and experimental group (TRX) for the experimental group in

\section{Assiut Journal For Sport Science Arts}


Improve some fitness elements and performance level for rowing players.

Search procedures:

First:

Research Methodology:

The researcher used the experimental method in the approach of pre and post measurement using two groups, one experimental and the other a control, in order to suit the nature of the research.

Community and Sample Search:

The research community includes rowing players in the Arab Contractors Club. The sample was randomly selected by the rowing players for the training season (2014-2015) for the age level under (13) years.

The number of players was 40 and the player was divided into 30 groups. (15) Players, and a control group of (15) player, and (10) player for the exploratory experiment to conduct scientific and exploratory study of the research and table (1) shows homogeneity in the sample of the research.

Table (1)

Arithmetic mean, standard deviation and torsion coefficient for measurements Age, height, weight and age of training of the research sample members $N=40$

\begin{tabular}{|c|c|c|c|c|c|}
\hline Variables & $\begin{array}{c}\text { Measuring } \\
\text { unit }\end{array}$ & $\begin{array}{c}\text { Arithmetic } \\
\text { mean }\end{array}$ & $\begin{array}{l}\text { standard } \\
\text { deviation }\end{array}$ & Mediator & $\begin{array}{c}\text { torsion } \\
\text { coefficient }\end{array}$ \\
\hline Height & $\mathrm{Cm}$ & 148.91 & 3.82 & 15.00 & -0.86 \\
\hline Weight & $\mathrm{Kg}$ & 44.58 & 3.62 & 44.00 & 0.48 \\
\hline Age & Year & 12.66 & 0.98 & 12.50 & 0.49 \\
\hline $\begin{array}{c}\text { Training } \\
\text { age } \\
\end{array}$ & Year & 2.70 & 0.25 & 2.60 & 1.20 \\
\hline \multicolumn{3}{|c|}{$\begin{array}{l}\text { It is clear from Table (1) } \\
\text { that all the values of the } \\
\text { arithmetic mean exceed the } \\
\text { values of the standard } \\
\text { deviations, and that all the }\end{array}$} & \multicolumn{3}{|c|}{$\begin{array}{l}\text { values of the torsion } \\
\text { coefficients were limited to } \\
(+/-3) \text { indicating the } \\
\text { homogeneity of the sample } \\
\text { members and their absence }\end{array}$} \\
\hline \multicolumn{6}{|c|}{ Assiut Journal For Sport Science Arts } \\
\hline
\end{tabular}


from the irregular distribution question.)

defects. (In the sample of 
Table (2)

Arithmetic mean, standard deviation, and torsion coefficient of physical variables

\begin{tabular}{|c|c|c|c|c|c|c|}
\hline \multicolumn{2}{|c|}{ Variables } & $\begin{array}{c}\text { Measuring } \\
\text { unit }\end{array}$ & $\begin{array}{c}\text { Arithmetic } \\
\text { mean }\end{array}$ & $\begin{array}{l}\text { standard } \\
\text { deviation }\end{array}$ & Mediator & $\begin{array}{c}\text { torsion } \\
\text { coefficient }\end{array}$ \\
\hline $\begin{array}{l}\text { Strength } \\
\text { of the } \\
\text { arms } \\
\text { muscle }\end{array}$ & $\begin{array}{l}\text { Test of } \\
\text { lying } \\
\text { Italic } \\
\text { modifier }\end{array}$ & No. & 11.86 & 0.59 & 12.00 & 0.03 \\
\hline $\begin{array}{l}\text { Strength } \\
\text { of } \\
\text { abdominal } \\
\text { muscles }\end{array}$ & $\begin{array}{l}\text { Test the } \\
\text { sitting of } \\
\text { the } \\
\text { supine }\end{array}$ & No. & 21.25 & 0.91 & 21.50 & -0.29 \\
\hline $\begin{array}{l}\text { Strength } \\
\text { of leg } \\
\text { muscles }\end{array}$ & $\begin{array}{l}\text { Test of } \\
\text { leg } \\
\text { strength } \\
\text { in } \\
\text { Dinamo } \\
\text { Mitter }\end{array}$ & $\mathrm{kg}$ & 51.13 & 0.82 & 51.00 & -0.26 \\
\hline $\begin{array}{l}\text { Strength } \\
\text { of back } \\
\text { muscles }\end{array}$ & $\begin{array}{l}\text { Test the } \\
\text { strength } \\
\text { of the } \\
\text { electrified } \\
\text { midfield }\end{array}$ & $\mathrm{Kg}$ & 54.40 & 1.22 & 54.00 & 0.61 \\
\hline $\begin{array}{l}\text { The } \\
\text { ability of } \\
\text { the legs }\end{array}$ & $\begin{array}{l}\text { Test the } \\
\text { wide } \\
\text { jump of } \\
\text { stability } \\
\end{array}$ & $\mathrm{Cm}$ & 143.75 & 6.44 & 142.50 & 0.24 \\
\hline $\begin{array}{l}\text { Arm } \\
\text { capacity }\end{array}$ & $\begin{array}{l}\text { Test } \\
\text { threw a } \\
\text { medical } \\
\text { ball for } \\
\text { the } \\
\text { farthest } \\
\text { distance }\end{array}$ & M & 6.55 & 0.43 & 6.50 & 0.25 \\
\hline $\begin{array}{l}\text { Shoulders } \\
\text { Elastic }\end{array}$ & $\begin{array}{l}\text { Test the } \\
\text { flexibility } \\
\text { of the } \\
\text { horizontal } \\
\text { shoulders }\end{array}$ & $\mathrm{Cm}$ & 43.25 & 1.10 & 43.10 & 0.05 \\
\hline $\begin{array}{l}\text { Back } \\
\text { flexibility }\end{array}$ & $\begin{array}{l}\text { Test the } \\
\text { trunk for } \\
\text { the front } \\
\text { of the } \\
\text { stand }\end{array}$ & $\mathrm{Cm}$ & 10.36 & 0.94 & 10.40 & 0.15 \\
\hline
\end{tabular}


It is clear from Table (2) that the torsion coefficient is limited to $\quad(-0.29-0.61)$. This means that the variables achieve the mean curve, where the $(+/-3)$ is limited. This confirms the degree of homogeneity between the samples as a whole in the physical variables.

\section{Table (3)}

Arithmetic mean, standard deviation and torsion coefficient of performance For sample members

\begin{tabular}{|c|c|c|c|c|c|c|c|c|c|c|}
\hline \multicolumn{2}{|c|}{ Variables } & \multicolumn{2}{|c|}{$\begin{array}{c}\text { Measuring } \\
\text { unit }\end{array}$} & \multicolumn{2}{|c|}{$\begin{array}{c}\text { Arithmetic } \\
\text { mean }\end{array}$} & \multicolumn{2}{|c|}{$\begin{array}{l}\text { standard } \\
\text { deviation }\end{array}$} & \multicolumn{2}{|c|}{ Mediator } & $\begin{array}{c}\text { torsion } \\
\text { coefficient }\end{array}$ \\
\hline \multirow{2}{*}{$\begin{array}{l}\text { The } \\
\text { 2000m } \\
\text { Argometer }\end{array}$} & $\begin{array}{l}\text { Number } \\
\text { of } \\
\text { wrenches }\end{array}$ & \multicolumn{2}{|c|}{ No. } & \multicolumn{2}{|l|}{ TI. } & \multicolumn{2}{|c|}{$\cdot .7 \Lambda$} & \multicolumn{2}{|c|}{ r... } & $\because \cdot r$ \\
\hline & Time & \multicolumn{2}{|c|}{ Min. } & \multicolumn{2}{|l|}{ V.0 } & \multicolumn{2}{|c|}{.$r^{\prime \prime}$} & \multicolumn{2}{|l|}{ V.o. } & $\because \cdot r$ \\
\hline $\begin{array}{l}\text { Perform } 30 \\
\text { minutes on } \\
\text { the } \\
\text { Argometer } \\
\end{array}$ & Distance & \multicolumn{2}{|c|}{ Kilometer } & \multicolumn{2}{|l|}{$7 . r 7$} & \multicolumn{2}{|c|}{$\cdot r V$} & \multicolumn{2}{|l|}{7.79} & $-\cdot \leq 1$ \\
\hline \multicolumn{11}{|c|}{$\begin{array}{ll}\text { It is clear from Table (3) } & \text { Equ } \\
\text { that the torsion coefficient is } & \text { resea } \\
\text { limited to }(-0.46-0.03) . & \\
\text { This means that the variables } & \text { the } 1 \\
\text { achieve the average curve, } & \text { two } \\
\text { where it is limited to }(+/-3) & (15) \\
\text { which confirms the degree of } & \text { and } \\
\text { homogeneity among the } & \text { make } \\
\text { sample as a whole in the } & \text { them } \\
\text { performance level variables. }\end{array}$} \\
\hline \multirow{2}{*}{\multicolumn{3}{|c|}{ Variables }} & \multicolumn{2}{|c|}{$\begin{array}{c}\text { The } \\
\text { experimental } \\
\text { group } N=15\end{array}$} & \multicolumn{3}{|c|}{$\begin{array}{c}\text { The control } \\
\text { group } \\
\mathbf{N}=15 \\
\end{array}$} & \multirow[t]{2}{*}{$\begin{array}{l}\text { Value } \\
\text { of the } \\
\text { "T" }\end{array}$} & \multirow{2}{*}{\multicolumn{2}{|c|}{$\begin{array}{c}\text { level of } \\
\text { significance }\end{array}$}} \\
\hline & & & $\mathrm{s}$ & $\mathrm{e}$ & $\mathrm{s}$ & & $\mathrm{e}$ & & & \\
\hline \multirow{2}{*}{$\begin{array}{l}\text { Physical } \\
\text { variables }\end{array}$} & $\begin{array}{l}\text { Adjusta } \\
\text { slant tes }\end{array}$ & & 11.83 & 0.58 & 11 & & 0.67 & 0.831 & & $\begin{array}{l}\text { Non } \\
\text { gnificant }\end{array}$ \\
\hline & $\begin{array}{l}\text { Test } \\
\text { sitting }\end{array}$ & $\begin{array}{l}\text { the } \\
f \text { the }\end{array}$ & 21.33 & 0.89 & & & 0.90 & 0.867 & & $\begin{array}{l}\text { Non } \\
\text { gnificant }\end{array}$ \\
\hline
\end{tabular}

Assiut Journal For Sport Science Arts 


\begin{tabular}{l|l|l|l|l|l|l|l}
\hline & supine & & & & & & \\
\cline { 2 - 7 } & $\begin{array}{l}\text { Test the legs of } \\
\text { Dinamo Mitter }\end{array}$ & 51.01 & 0.85 & 50.93 & 0.79 & 1.01 & $\begin{array}{c}\text { Non } \\
\text { significant }\end{array}$ \\
\hline \hline
\end{tabular}

\section{Follow Table (4)}

Indication of differences between experimental and control groups in tribal measurement For search variables

\begin{tabular}{|c|c|c|c|c|c|c|c|}
\hline \multirow{2}{*}{\multicolumn{2}{|c|}{ Variables }} & \multicolumn{2}{|c|}{$\begin{array}{c}\text { The } \\
\text { experimental } \\
\text { group } N=15\end{array}$} & \multicolumn{2}{|c|}{$\begin{array}{c}\text { The control } \\
\text { group } \\
\mathbf{N}=15 \\
\end{array}$} & \multirow[t]{2}{*}{$\begin{array}{l}\text { Value } \\
\text { of the } \\
\text { "T" }\end{array}$} & \multirow[t]{2}{*}{$\begin{array}{c}\text { level of } \\
\text { significance }\end{array}$} \\
\hline & & $\mathrm{s}$ & $\mathrm{e}$ & s & $\mathrm{e}$ & & \\
\hline & $\begin{array}{l}\text { Test the } \\
\text { strength of the } \\
\text { back of the } \\
\text { dynamo meter }\end{array}$ & 54.47 & 0.99 & 54.23 & 1.45 & 0.62 & $\begin{array}{c}\text { Non } \\
\text { significant }\end{array}$ \\
\hline & $\begin{array}{l}\text { Test the wide } \\
\text { jump of } \\
\text { stability }\end{array}$ & 142.60 & 1.24 & 142.67 & 1.35 & 0.14 & $\begin{array}{c}\text { Non } \\
\text { significant }\end{array}$ \\
\hline & $\begin{array}{l}\text { Test threw a } \\
\text { medical ball } \\
\text { for the farthest } \\
\text { distance }\end{array}$ & 1.43 & 0.21 & 6.41 & 0.58 & 0.45 & $\begin{array}{c}\text { Non } \\
\text { significant }\end{array}$ \\
\hline & $\begin{array}{l}\text { Test the } \\
\text { flexibility of } \\
\text { the horizontal } \\
\text { shoulders }\end{array}$ & 42.67 & 1.59 & 42.69 & 1.30 & 0.04 & $\begin{array}{c}\text { Non } \\
\text { significant }\end{array}$ \\
\hline & $\begin{array}{l}\text { Test the trunk } \\
\text { for the front } \\
\text { of the stand }\end{array}$ & 11.20 & 0.94 & 10.94 & 0.85 & 0.77 & $\begin{array}{c}\text { Non } \\
\text { significant }\end{array}$ \\
\hline \multirow{2}{*}{$\begin{array}{l}\text { Race } 2000 \\
\mathrm{~m} \\
\text { Argometer }\end{array}$} & $\begin{array}{l}\text { Average } \\
\text { number } \\
\text { wrenches }\end{array}$ & 31.75 & 0.75 & 31.67 & 0.651 & 0.290 & $\begin{array}{c}\text { Non } \\
\text { significant }\end{array}$ \\
\hline & Time & 7.57 & 0.25 & 7.54 & 0.23 & 0.260 & $\begin{array}{c}\text { Non } \\
\text { significant }\end{array}$ \\
\hline Perform & Distance & 6.68 & 0.23 & 6.60 & 0.28 & 0.775 & Non \\
\hline
\end{tabular}

*The value of the table "T" at a significant level of $0.05=1.699$

It is clear from the of "T" are not the same as all previous table that the values of them are less than the "T" 
values in the table at a significant level of 0.05 . This indicates the equivalence of the members of the research sample in the research variables.

\section{Data collection tools:}

First: Tools and devices:

The researcher used the following tools and tools during measurements and program:

* TRX Suspension Device Attachment (9)

* Argometer device

* Dynamometer to measure the muscle strength of the two men and the back

* Medical balance device to measure the weight of the nearest $\mathrm{kg}$.

* Resistameter device to measure the length of the nearest $\mathrm{cm}$.

* Stopwatch to measure time.

* Sports mattresses.

* Swedish seat.

* Meter for distance

measurement.

* Medical ball.

* Seat without back.

* Ruler included.

Second: Forms and interviews:

The researcher studied the reference of scientific references and previous Arab and foreign studies specialized in the field of sports training in general and the training of rowing in particular to identify and identify the most important and appropriate elements of fitness for rowing, and the researcher designed:

- A questionnaire for the opinion of the experts to determine the most important elements of fitness for rowing. The names of the experts and the conditions of their selection shall appear in Annex 1, while the form of their questionnaire on the elements of fitness and the tests required for their measurement shall appear (Annex 2.)

- A questionnaire for the opinion of the experts to determine the suitability of the fitness training used and the time distribution of the training module (Annex 3)

- A data collection form to record data for each player. (Annex 4)

Third: physical tests and performance level under consideration:

- Physical tests:

- Italic slant test (for girls) to measure the strength of the arms. (11: 186)

-Test the sitting of the bowel and bend the knees to measure the strength of the abdominal muscles. (11:59)

-Test the strength of the muscles of the two legs to 
measure the strength of the muscles of the two legs. (11: 29)

-Test the strength of the back muscles to measure the muscle strength of the material for the back. (11: 32)

-Wide-jump test of stability to measure the muscular capacity of both legs (11: 93)

-Select to push a medical ball to the farthest distance to measure the arms (11: 110)

-Flexibility test of the horizontal shoulders to measure the flexibility of the shoulders

-Test the torso of the front of the stand to measure the flexibility of the back (11:341)

-Test the level of performance:

* Argometer test to calculate the number of wrenches

* Argometer test for time calculation

* Argometer test to calculate distance

Training program using the proposed TRX
First: the objective of the program

The proposed TRAX training program aims to:

1-Improved some fitness elements for rowing players

-Upgrading the performance of the rowing players on the Argometer

Third: Design of the proposed program

Based on the opinion of experts specialized in rowing, swimming, access to scientific references, previous studies and the information network, the following has been identified:

1 -Period of application of the proposed program using the TRX device $=$ three months $=$ (12 weeks.)

$r$-Number of training units per week $=3$ training modules.

$r$-Number of training units during the proposed training program $=3$ units $\times 10$ weeks $=30$ training modules.

$\varepsilon$-The average training time for the TRX is between $60-70$ minutes.

Table (5)

shows the percentage of opinion of the experts

Table (5) Percentage of expert opinion on the duration of the proposed training program using the TRX

\begin{tabular}{l|c|c}
\hline \hline Components of the training program using & Period & $\begin{array}{l}\text { Percentage of } \\
\text { compliance }\end{array}$ \\
\hline \hline
\end{tabular}

Assiut Journal For Sport Science Arts 


\section{the TRX}

\begin{tabular}{l|l|c}
\hline \hline Program Period & 3 months & $100 \%$ \\
\hline Number of training units per week & 3 units & $90 \%$ \\
\hline Average training time with the TRX module & $(60)$ min & $80 \%$ \\
\hline Training Method & $\begin{array}{l}\text { low intensity } \\
\text { Period }\end{array}$ & $90 \%$ \\
\hline \hline
\end{tabular}

Table (8) shows the components of the proposed training program and the percentage of each of the components of the proposed training program according to the expert opinions. The and the level of performance

\begin{tabular}{|c|c|c|c|c|c|c|c|c|}
\hline \multirow[t]{2}{*}{ Variables } & \multirow{2}{*}{\multicolumn{2}{|c|}{$\begin{array}{l}\text { measuring } \\
\text { unit }\end{array}$}} & \multicolumn{2}{|c|}{$\begin{array}{c}\text { Pre } \\
\text { measurement }\end{array}$} & \multicolumn{2}{|c|}{$\begin{array}{c}\text { Post } \\
\text { measurement }\end{array}$} & \multirow[t]{2}{*}{$\begin{array}{l}\text { Values } \\
\text { "T" }\end{array}$} & \multirow[t]{2}{*}{ Change \% } \\
\hline & & & $\mathbf{m}$ & e & $\mathbf{m}$ & e & & \\
\hline \multirow{4}{*}{$\begin{array}{l}\text { Tests of } \\
\text { muscle } \\
\text { strength }\end{array}$} & $\begin{array}{l}\text { Strength of } \\
\text { the } \\
\text { muscles of } \\
\text { the arms }\end{array}$ & No. & 11.83 & 0.58 & 16.33 & 0.65 & 23.21 & $38.04 \%$ \\
\hline & $\begin{array}{l}\text { Strength of } \\
\text { abdominal } \\
\text { muscles }\end{array}$ & No. & 21.33 & 0.89 & 25.83 & 0.89 & 10.78 & $21.20 \%$ \\
\hline & $\begin{array}{l}\text { Muscle } \\
\text { Strength Legs }\end{array}$ & $\mathrm{kg}$. & 51.01 & 0.85 & 54.40 & 0.63 & 20.82 & $6.65 \%$ \\
\hline & $\begin{array}{l}\text { Strength of } \\
\text { back } \\
\text { muscles }\end{array}$ & $\mathrm{Kg}$. & 54.47 & 0.99 & 57.47 & 1.18 & 21.74 & $5.51 \%$ \\
\hline \multirow{2}{*}{$\begin{array}{l}\text { Muscle } \\
\text { capacity }\end{array}$} & $\begin{array}{l}\text { The ability } \\
\text { of the legs }\end{array}$ & $\mathrm{Cm}$ & 142.6 & 1.24 & 148.75 & 0.45 & 17.44 & $4.31 \%$ \\
\hline & $\begin{array}{l}\text { Arm } \\
\text { capacity }\end{array}$ & $\mathrm{Cm}$ & 6.43 & 0.21 & 7.87 & 0.52 & 3.58 & $22.39 \%$ \\
\hline Flexibility & $\begin{array}{l}\text { Elastic of } \\
\text { shoulders }\end{array}$ & $\mathrm{Cm}$ & 42.67 & 1.59 & 39.56 & 0.51 & 6.97 & $2.28 \%$ \\
\hline
\end{tabular}

Assiut Journal For Sport Science Arts percentage of the approval of the experts on the proposed training program is $80 \%$ to $100 \%$.

View and discuss results

View results

\section{Table (6) \\ The significance of the differences between the tribal and remote
measurements of the experimental group in the physical variables \\ The significance of the differences between the tribal and remote
measurements of the experimental group in the physical variables}

and the level of performance 


\begin{tabular}{l|l|c|c|c|c|c|c|c}
\hline \hline & $\begin{array}{l}\text { Back } \\
\text { flexibility }\end{array}$ & $\mathrm{Cm}$ & 11.20 & 0.94 & 14.80 & 1.28 & 8.48 & $32.14 \%$ \\
\hline $\begin{array}{l}\text { The } \\
\begin{array}{l}\text { Argom } \\
\text { Argometer }\end{array}\end{array}$ & $\begin{array}{l}\text { Average } \\
\text { number of } \\
\text { wrenches }\end{array}$ & $\begin{array}{c}\text { Number } \\
\text { of } \\
\text { wrenches }\end{array}$ & 31.75 & 0.75 & 29.17 & 0.39 & 13.39 & $8.13 \%$ \\
\cline { 2 - 9 } $\begin{array}{l}\text { Perform 30 } \\
\text { minutes on the } \\
\text { Argometer }\end{array}$ & Distance & Time & 7.57 & 0.25 & 7.02 & 0.36 & 4.04 & $7.27 \%$ \\
\hline \hline
\end{tabular}

The value of the table "T" at a significant level of $0.05=1,761$

Table (6) shows the of the post-measurement of the existence of statistically research sample in the significant differences in favor variables in question.

Table (7)

The significance of the differences between the tribal and remote measurements of the control group in the physical variables and the level of performance $N=15$

\begin{tabular}{|c|c|c|c|c|c|c|c|c|}
\hline \multirow{2}{*}{\multicolumn{2}{|c|}{ Variables }} & \multirow[t]{2}{*}{$\begin{array}{c}\text { Measuring } \\
\text { unit }\end{array}$} & \multicolumn{2}{|c|}{ Pre measurement } & \multicolumn{2}{|c|}{$\begin{array}{c}\text { Post } \\
\text { measurement }\end{array}$} & \multirow[t]{2}{*}{$\begin{array}{l}\text { Values } \\
\text { "T" }\end{array}$} & \multirow[t]{2}{*}{ Change $\%$} \\
\hline & & & $\mathrm{m}$ & $\mathrm{e}$ & $\mathrm{m}$ & $\mathrm{e}$ & & \\
\hline \multirow{4}{*}{$\begin{array}{l}\text { Tests of } \\
\text { muscle } \\
\text { strength }\end{array}$} & $\begin{array}{l}\text { Strength of } \\
\text { the muscles } \\
\text { of the arms }\end{array}$ & No. & 11.92 & 0.67 & 13.00 & 0.85 & 3.463 & $9.06 \%$ \\
\hline & $\begin{array}{c}\text { Strength of } \\
\text { abdominal } \\
\text { muscles }\end{array}$ & No. & 21.41 & 0.90 & 22.83 & 0.83 & 4.529 & $6.63 \%$ \\
\hline & $\begin{array}{l}\text { Muscle } \\
\text { Strength } \\
\text { Legs }\end{array}$ & $\mathrm{kg}$. & 50.93 & 0.79 & 52.33 & 0.97 & 10.69 & $2,75 \%$ \\
\hline & $\begin{array}{l}\text { Strength of } \\
\text { back } \\
\text { muscles }\end{array}$ & Kg. & 54.23 & 1.45 & 55.32 & 1.63 & 10.25 & $1,82 \%$ \\
\hline \multirow{2}{*}{$\begin{array}{l}\text { Muscle } \\
\text { capacity }\end{array}$} & $\begin{array}{l}\text { The ability } \\
\text { of the legs }\end{array}$ & $\mathrm{Cm}$ & 142.67 & 1.35 & 144.12 & 0.83 & 3.45 & $1,02 \%$ \\
\hline & $\begin{array}{c}\text { Arm } \\
\text { capacity }\end{array}$ & $\mathrm{Cm}$ & 6.41 & 0.58 & 6.88 & 0.28 & 2.47 & $7.33 \%$ \\
\hline \multirow{2}{*}{ Flexibility } & $\begin{array}{l}\text { Elastic of } \\
\text { shoulders }\end{array}$ & $\mathrm{Cm}$ & 42.69 & 1.30 & 40.11 & 0.52 & 6.89 & $6,04 \%$ \\
\hline & $\begin{array}{c}\text { Back } \\
\text { flexibility }\end{array}$ & $\mathrm{Cm}$ & 10.94 & 0.85 & 12.81 & 0.68 & 6.43 & $17,09 \%$ \\
\hline \multirow[t]{2}{*}{$\begin{array}{c}\text { The } \\
\text { 2000m } \\
\text { Argometer }\end{array}$} & $\begin{array}{c}\text { Average } \\
\text { number of } \\
\text { wrenches }\end{array}$ & $\begin{array}{c}\text { Number } \\
\text { of } \\
\text { wrenches }\end{array}$ & 31.67 & 0.651 & 30.41 & 0.51 & 6.966 & $3.97 \%$ \\
\hline & Time & Time & 7.54 & 0.23 & 7.28 & 0.10 & 3.125 & $3.70 \%$ \\
\hline
\end{tabular}




\begin{tabular}{c|l|l|l|l|l|l|l|l}
\hline $\begin{array}{c}\text { Perform } \\
30 \\
\text { minutes } \\
\text { on the } \\
\text { Argometer }\end{array}$ & Distance & Distance & 6.60 & 0.28 & 6.94 & 0.44 & 2.422 & $5.15 \%$ \\
\hline \hline
\end{tabular}

The value of the function "T" is at a significant level of $0.05=1,761$

Table (7) shows the of the post-measurement of the existence of statistically research sample in the significant differences in favor variables in question. 
Table (8)

Indication of the differences between the post-measurement of the experimental group and the control group In physical variables and level of performance $N=1 \mathrm{n}=15$

\begin{tabular}{|c|c|c|c|c|c|c|c|}
\hline \multirow{2}{*}{\multicolumn{2}{|c|}{ Variables }} & \multirow[t]{2}{*}{$\begin{array}{c}\text { Measuring } \\
\text { unit }\end{array}$} & \multicolumn{2}{|c|}{$\begin{array}{l}\text { Experimental } \\
\text { group }(15)\end{array}$} & \multicolumn{2}{|c|}{$\begin{array}{c}\text { Control } \\
\text { group (15) }\end{array}$} & \multirow[t]{2}{*}{$\begin{array}{c}\mathbf{T} \\
\text { value }\end{array}$} \\
\hline & & & $\mathbf{m}$ & e & $\mathbf{m}$ & e & \\
\hline \multirow{4}{*}{$\begin{array}{l}\text { Tests of } \\
\text { muscle } \\
\text { strength }\end{array}$} & No. & No. & 16.33 & 0.65 & 13.00 & 0.85 & $10.761^{*}$ \\
\hline & No. & No. & 25.83 & 0.89 & 22.83 & 0.83 & $8.802^{*}$ \\
\hline & kg. & $\mathrm{Kg}$ & 54.40 & 0.63 & 52.33 & 0.97 & $6,88^{*}$ \\
\hline & Kg. & $\mathrm{Kg}$ & 57.47 & 1.18 & 55.32 & 1.63 & $4,09 *$ \\
\hline \multirow{2}{*}{$\begin{array}{l}\text { Muscle } \\
\text { capacity }\end{array}$} & $\mathrm{Cm}$ & $\mathrm{Cm}$ & 148.75 & 0.45 & 144.12 & 0.83 & $18.31 *$ \\
\hline & $\mathrm{Cm}$ & $\mathrm{Cm}$ & 7.87 & 0.52 & 6.88 & 0.28 & $3.265 *$ \\
\hline \multirow{2}{*}{ Flexibility7 } & $\mathrm{Cm}$ & $\mathrm{Cm}$ & 39.56 & 0.51 & 40.11 & 0.52 & $2.83 *$ \\
\hline & $\mathrm{Cm}$ & $\mathrm{Cm}$ & 14.80 & 1.28 & 12.81 & 0.68 & $5.14 *$ \\
\hline \multirow[t]{2}{*}{$\begin{array}{l}\text { The } 2000 \mathrm{~m} \\
\text { Argometer }\end{array}$} & $\begin{array}{c}\text { Number } \\
\text { of } \\
\text { wrenches }\end{array}$ & No & 29.17 & 0.39 & 30.41 & 0.51 & $8.670^{*}$ \\
\hline & Time & Time & 7.02 & 0.36 & 7.28 & 0.10 & $2.390 *$ \\
\hline $\begin{array}{l}\text { Perform } 30 \\
\text { minutes on } \\
\text { the } \\
\text { Argometer }\end{array}$ & Distance & $\mathrm{Km}$ & 7.42 & 0.40 & 6.94 & 0.44 & $2.756^{*}$ \\
\hline
\end{tabular}

The value of the function " $T$ " is at a significant level of $0.05=1,699$

Table (8) shows statistically significant differences between the two research groups in the issue's variables.

\section{Discussion of results:}

Table (6) shows statistically significant differences between mean and post measurements of the experimental group in tests of physical variables, as well as performance level tests (2000-Argumenter-30 s on
Argometer) in favor of telemetry. At the significance level (0.05).

The researcher attributed this improvement to the use of the proposed program using the TRX attachment device used with rowing players in the experimental group.

In this regard, Burns (2007) states that TRX attachment training is one of the forms of 
functional resistance training aimed at directing the resulting force in the direction of performance and performing in multi-level and integrated movements. (7:17)

Danielle Dannelly, et al. (2011) suggests that attachment exercises increase the area of the musculoskeletal segment and the thick muscular fibroblast in the trained muscle by focusing on the muscles of the center, thus increasing the muscle fiber and thus increasing the amount of protein in the muscle, which leads to the acquisition of the muscle tone (150: 18)

The researcher attributed the improvement in the level of performance in the post-test due to the improvement of physical variables through TRX training

This result is consistent with the view of Essam AbdelKhaliq (2003) and Owais AlJibali (2000) that many researchers and specialists in the field of sports agree on a strong correlation between physical abilities and skill level. The athlete cannot master the basic skills of the type of activity (55:7) (51:8), and in the case of the physical،
The researcher attributed the occurrence of these changes and development in the physical requirements and the level of performance on the Argometer to the good planning of the training program of attachment to the TRX and the standardization of training loads in a scientific manner suitable for the stage and the training of the research sample and the use of attachment exercises to develop muscle strength of all kinds, During the application of the program by training various muscle groups, especially the muscles of the arms and legs and the focus of the researcher on the muscle groups working during the paddle,

which led to the improvement of the physical variables under consideration You may have achieved the first hypothesis, which states that there are statistically significant differences between the premeasurement and the postmeasurement of the experimental group

For the benefit of telemetry in improving some elements of 
fitness and performance level of rowing players

Table 7 shows statistically significant differences between mean and post measurements of the control group in tests of physical variables, as well as the performance level tests (2000-Argumenter-30 s on the Argometer) for the benefit of the telemetry. The calculated value (t) At the level of significance (0.05).

The same table shows the slight change rate between the pre and post measurements of the control group in the elements of fitness in question.

The researcher returned the slight improvement compared to the improvement in the experimental group to regularity of the research sample in the presence of physical and skill training and Program followed them and the subject

This is consistent with the study of "Fatima Said" (2002) (9) that the use of the tools helps to develop fitness elements so prefer to use them in warm and numbers of physical because of their active role in attracting attention and enjoy the performance and thus the development of elements of physical fitness better.

In addition, Mokhtar Abdul Hafiz (2006) emphasizes that success in any basic defensive or offensive skill requires the development of essential physical components that contribute to its ideal performance and that each basic skill contributes to its performance according to its nature rather than a physical component.

And thus it has achieved a second hypothesis which states there are statistically significant differences between the measurement of pre and post control group in favor of post in improving some elements of physical fitness and performance level of players rowing.

Table (8) shows that statistically significant differences were found between the mean measurements of the experimental and control groups in the tests of physical and skill variables in favor of the experimental group where the calculated value (t) was greater than the tabular value at the significance level (0.05). Use TRX attachment device 
drills used with kayaking players in the experimental group.

The researcher believes that the reason for the improvement of the elements of fitness and performance level is due to the TRX device used in the application of the program has achieved high results and should be used in the preparation period for all sports to raise the level of physical fitness and skill.

Beijing Pagan (2005) notes that attachment training is suitable for all individuals at different levels of training and aims to improve the relationship between muscles and the nervous system by converting the increase in strength gained from one movement to another.

Therefore, locomotor training exercises are necessary and important, Individuality through movement. (110: 25) This is in line with Victor Dulceață's (2011) observation that suspension training is a revolution in the world of sports training.

It is an advanced form of resistance training designed to develop muscle strength in all its forms without the use of weight or other forms of resistance. With Normal performance. (110: 25) (29)

The training exercises are simple exercises and easy to use, and this is evident in the fact that the exercises are characterized by simplicity and can be graduated in the intensity of the weak intensity of the maximum, and is aimed at improving balance, flexibility, compatibility and muscle strength. (19:17)

Thus, the third hypothesis, which states that there are statistically significant differences between the two dimensions of the control group (the traditional method) and the experimental group (TRX) for the experimental group, has been achieved in improving some of the fitness elements and the level of performance of the rowing players .

\section{Conclusions}

- IThe

suspension

exercises using TRX have had a positive effect on improving the physical abilities of rowing - $\quad$ TTriggering exercises using TRX have had a positive effect on the improvement of the performance-related technical variables on the 
Argometer device for traction ramps

- rThe suspension exercise using TRX has had a better effect than the program on improving the special physical abilities and skill performance on the Argometer in rowing players

\section{Recommendations}

- IThe use of the TRX suspense training device because of its positive effect on improving the physical variables in physical preparation programs in rowing.

- $\quad r$ Use the TRX suspense training device instead of the weight training exercises for the beginners to eliminate injuries that may occur to those age group of weight training.

- r-Conduct further studies on the impact of TRX training on other physical abilities in different sports.

\section{References}

\section{1- Abdul-Aziz Al-Nimr,} Nariman Al-Khatib: Physical preparation and weight training in pre-puberty, professors of sports book, Cairo, 2000

2- Abu El-Ela Ahmed AbdelFattah, Hazem Hussein Salem: Contemporary Trends in Swimming Training, Dar Al-
Fikr Al-Arabi First Printing, Cairo, 2011

3- Aweys Ali Al-Habali: Mathematical Training Theory and Practice, GMS Publishing, Cairo 2000.

\section{4- Bastoise Ahmed Bastawisi:}

Foundations and theories of sports training, Dar al-Fikr alArabi, 1999

\section{5 -}

Burns

Nick

(2007). "Suspension Training: How Risky Is It?" The New York Times. Retrieved.

\section{6- Dalia Radwan (2014):} Effect of the use of the TRX device suspended in the lesson of physical education on some elements of fitness for students in the preparatory stage, A master thesis, unpublished, Faculty of Physical Education, Helwan University.

7- Dannelly BD, Otey SC, Croy T, Harrison B, Rynders C, Hertel J, Weltman A. (2011): The effectiveness of traditional and sling exercise strength training in novice women, Journal of Strength and Conditioning Research 2011;25 (2):464-71

\section{8- Dalia Radwan (2014):}

Effect of the use of the TRX device suspended in the lesson of physical education on some elements of fitness for students 
in the preparatory stage, A master thesis, unpublished, Faculty of Physical Education, Helwan University.

9- Dudgeon, W D; Aartun, J D; Thomas, D D; Herrin, J; Scheett, T P (2011): Effects of Suspension Training on the Growth Hormone Axis, Journal of Strength \& Conditioning Research, March - Volume 25 - Supplement

10- Essam Abdel Khalek: Physical Training, "Theories and Applications", I 11, Monshaat Almaref Alexandria, 2003.

11- Huang JS, Pietrosimone BP, Ingersoll CD, Arthur L. Weltman A, Saliba SA. (2011): Sling Exercise and Traditional Warm-Up Have Similar Effects on the Velocity and Accuracy of Throwing. Journal of Strength and Conditioning Research 2011; Epub ahead of print

\section{2- Fatima Said Gharib:}

"The Effect of the Introductory Games Program on Special Fitness and Handy Performance in Handball for Preparatory Girls", Master Thesis, unpublished, Faculty of
Physical Education Girls, Helwan University, 2002.

13- Kamal Abdel Hamid, Mohamed Sobhy Hassanein: Physical Fitness and its Components, Theoretical Basis, Physical Preparation and Methods of Measurement, 3, Dar Al-Fikr Al-Arabi, Cairo, 1997

\section{4- Khalid Mohammed}

Abdul Karim:: "The study of physical composition and fitness elements for short distance swimmers emerging," Unpublished master thesis, Faculty of Physical Education, Assiut University, 2002.

15- Kitchhner ,G.,: Physical Education For Elementary School Children,10th Ed, Me Graw Hill Companies, Inc, Boston ,USA, 2000.

16- Koprince, Susan. "Domestic Violence in A Streetcar Named Desire". Bloom's Modern Critical Interpretations: Tennessee William's A Streetcar Named Desire. Ed. Harold Bloom. New York: InfoBase Publishing, 2009. 49-60. Print 17- LI Weijun, CAO Jie (2011): Discussion on 
Suspension Training in Application to Basketball, Journal of Hubei Sports Science, Issue 5, Page 543-544 18- Maas, Anne, and Arcuri Luciano. "Language and Stereotyping". Stereotypes and Stereotyping. eds. Macrae, Neil C. et al. New York: Guilford Press. Google Books. 8 December 2011. Web

\section{9- Maryam Mustafa} Mohamed Salem (2015) The impact of a program using the TRX training device on the development of the fitness elements of some offensive skills for female basketball players, Master thesis, unpublished, Faculty of Physical Education, Helwan University.

20- Mohamed Hassan Allawi, Mohamed Nasr El-Din Radwan (2001): Performance tests, Arab Thought House, Cairo.

\section{1- Mohamed Hassan Allawi:} the psychology of training and sports competition, I 1, Dar alFikr al-Arabi, Cairo, 2002.

22- Mohamed Abdel Rahim Ismail: Training of muscle strength and weight programs for young people, 1, knowledge facility, Alexandria, 1998.

\section{3- Mokhtar Ibrahim Abdul}

Hafiz: Evaluation of swimming plans for swimmers short distances, unpublished $\mathrm{PhD}$ thesis, Faculty of Physical Education Benin University, 2006.

\section{4- Mufti Ibrahim Hammad:}

Modern Sports Training "Planning, Implementation and Leadership", I 2, Dar Al-Fikr Al-Arabi, Cairo, 2001.

\section{5- Pagan, Nicholas.}

"Nicholas Pagan on the Significance of Names." Bloom's Guides: Tennessee Williams's A Streetcar Named Desire. New York: Chelsea House Publishers, 2005. 107114. Print

\section{6- Saeterbakken AH, Van} Den Tillaar R, Seiler S. (2011): Effect of core stability training on throwing velocity in female handball players. The Journal of Strength and Conditioning Research; 25(3):712-18

27- Seiler et. Al (2006): Sling Exercise Training improves balance, kicking velocity and 
torso stabilization strength in elite soccer players. Medicine $\&$ Science in Sport \& Exercise 38(5):S243.

28- Seiler S, Skaanes P.T, Kirkesola G. (2006): Effects of Sling Exercise Training on maximal club head velocity in junior golfers, Medicine \& Science in Sports \& Exercise 38(5):S286

29- Weight Training, Design of Force Programs and Planning of the Training Season", The Book Center for Publishing, Cairo, 1996.

30- https://www.trxtraining. com/30http://en.wikipedia.org/ wiki/Suspension_training 31- http//www.completestrength-training.com/trxfitness

32- http://www.theguardian. com/

lifeandstyle/2007/jun/05/health andwellbeing.health3 